\title{
Colonic CD8 and $\gamma \delta$ T-cell infiltration with epithelial damage in children with autism
}

\author{
Raoul I. Furlano, MD, Andrew Anthony, PhD, Richard Day, PhD, Angela Brown, Louise McGarvey, \\ Michael A. Thomson, FRCPCH, Susan E. Davies, MRCPath, Mark Berelowitz, FRCPsych, \\ Alastair Forbes FRCP, Andrew J. Wakefield, FRCS, John A. Walker-Smith, FRCP, and Simon H. Murch, FRCP
}

Objectives: We have reported colitis with ileal lymphoid nodular hyperplasia (LNH) in children with regressive autism. The aims of this study were to characterize this lesion and determine whether LNH is specific for autism.

Methods: Ileo-colonoscopy was performed in 21 consecutively evaluated children with autistic spectrum disorders and bowel symptoms. Blinded comparison was made with 8 children with histologically normal ileum and colon, 10 developmentally normal children with ileal LNH, 15 with Crohn's disease, and 14 with ulcerative colitis. Immunohistochemistry was performed for cell lineage and functional markers, and histochemistry was performed for glycosaminoglycans and basement membrane thickness.

Results: Histology demonstrated lymphocytic colitis in the autistic children, less severe than classical inflammatory bowel disease. However, basement membrane thickness and mucosal $\gamma \delta$ cell density were significantly increased above those of all other groups including patients with inflammatory bowel disease. $\mathrm{CD} 8^{+}$density and intraepithelial lymphocyte numbers were higher than those in the Crohn's disease, LNH, and normal control groups; and CD3 and plasma cell density and crypt proliferation were higher than those in normal and LNH control groups. Epithelial, but not lamina propria, glycosaminoglycans were disrupted. However, the epithelium was HLA-DR ${ }^{-}$, suggesting a predominantly $\mathrm{T}_{\mathrm{H}} 2$ response.

Interpretation: Immunohistochemistry confirms a distinct lymphocytic colitis in autistic spectrum disorders in which the epithelium appears particularly affected. This is consistent with increasing evidence for gut epithelial dysfunction in autism. ( $\mathrm{J}$ Pediatr 2001;138:366-72)

A preliminary report in 12 children with regressive autism described unexpected colonic inflammation in association with ileal lymphoid nodular hy- perplasia. ${ }^{1}$ The colonic lesion of what we termed autistic enterocolitio was clearly not that of classical inflammatory bowel disease but was consistent

From the University Department of Paediatric Gastroenterology, the Inflammatory Bowel Diseases Study Group, the University Departments of Medicine and Histopathology, and the Department of Child and Adolescent Psychiatry, Royal Free and University College School of Medicine, London, United Kingdom; and the IBD Research Unit, St Mark's Hospital, Harrow, London, United Kingdom.

Supported by the Swiss National Science Foundation, M. und W. Lichtenstein-Stiftung, FAG Basel, Ciba-Geigy Jubiläums-Stiftung and Akademische Nachwuchsförderung der Universität Basel Switzerland (Dr Furlano) and by the Bailey Thomas Charitable Fund, the Basil Samuel Charitable Trust, the Normanby Charitable Trust, PF Charitable Trust, and the Sir Samuel Scott of Yews Charitable Trust.

Submitted for publication Apr 7, 2000; revisions received June 15, 2000, and Aug 3, 2000; accepted Aug 30, 2000.

Reprint requests: Simon Murch, PhD, FRCP, FRCPCH, University Department of Paediatric Gastroenterology, Royal Free and University College Medical School, Royal Free Campus, Rowland Hill St, London, NW3 2PF United Kingdom.

Copyright (C) 2001 by Mosby, Inc.

$0022-3476 / 2001 / \$ 35.00+0 \quad 9 / 21 / 111323$

doi: $10.1067 / \mathrm{mpd} .2001 .111323$

in over 150 subsequently evaluated children with autism, in whom the main gastrointestinal presentation was abdominal pain and either constipation

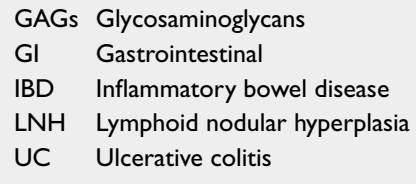

or diarrhea. ${ }^{2}$ It remains unclear whether this inflammation is characteristic for autism in general or found only in a subgroup with gastrointestinal symptoms. In view of striking recent increases in autistic spectrum disorders in both the United Kingdom and the United States, ${ }^{3,4}$ this required further study. 
Table I. Clinical details of autistic and control groups

\begin{tabular}{|c|c|c|c|c|c|c|c|}
\hline & Nos. & $M: F$ & Age (y) & $\operatorname{lgA}(g / L)$ & CRP $(\mathrm{mg} / \mathrm{dL})$ & $\mathrm{ESR}(\mathrm{mm} / \mathrm{h})$ & Constipation* \\
\hline Histologically normal & 8 & $4: 4$ & $10.3(2.7-13.3)$ & $1.0( \pm 0.2)$ & $2.2( \pm 0.6)$ & $7.8( \pm 1.4)$ & $1 / 8$ \\
\hline LNH controls & 10 & $4: 6$ & $10.1(2.7-13.9)$ & $0.8( \pm 0.2)$ & $2.0( \pm 0.6)$ & $9.5( \pm 1.9)$ & $9 / 10$ \\
\hline Autistic & 21 & $18: 3$ & $8.2(3.5-16.3)$ & $1.1( \pm 0.1)$ & $2.4( \pm 0.7)$ & $9.1( \pm 1.7)$ & $18 / 21$ \\
\hline Crohn's disease & 15 & $11: 4$ & $13.2(11.1-17.4)$ & $2.7( \pm 0.9)$ & $25.9( \pm 8.3)$ & $40.9( \pm 8.6)$ & $0 / 15$ \\
\hline UC & 14 & $10: 4$ & $13.4(10.3-17.6)$ & $2.0( \pm 0.2)$ & $5.3( \pm 8.1)$ & $29.1( \pm 9.2)$ & $0 / 14$ \\
\hline
\end{tabular}

Values given for age and blood test values represent group mean plus either range (age) or \pm SE (IgA, CRP, ESR).

$C R P$, C-reactive protein; $E S R$, erythrocyte sedimentation rate; $L N H$, lymphoid nodular hyperplasia; $U C$, ulcerative colitis.

*As determined from abdominal x-ray film.

LNH is not infrequently seen in the ileum of developmentally normal children with GI symptoms: it is often associated with minor immunodeficiency, when eosinophilic infiltration of the colon may occur. ${ }^{5,6}$ We now compare the colonic lesion in autistic children with that in developmentally normal children with ileal $\mathrm{LNH}$, in addition to histologically normal and disease control patients (IBD). The children with LNH had abdominal pain, poor weight gain, and loose stools and shared other characteristics with the patients with autism, including constipation, atopy, and low immunoglobulin levels ${ }^{2}$; they often had a clinical response to dietary exclusions but did not have any associated cognitive defect.

We report distinct abnormalities within the autistic group, with particular increases in CD8 and $\gamma \delta$ T-cell infiltration. The marked epithelial abnormalities seen coincide with increasing evidence of gut epithelial dysfunction in autism (excess permeability, ${ }^{7}$ protein leakage, ${ }^{8}$ aberrant peptide processing, ${ }^{9,10}$ and impaired sulfation ${ }^{11}$ ) and findings of small intestinal enteropathy ${ }^{12}$ to suggest possible functional significance.

\section{Patients AND Methods}

Transverse colon biopsy specimens were obtained from 21 children with autistic spectrum disorders, 14 patients with active ulcerative colitis, and 15 patients with active Crohn's disease. We obtained an additional 18 control specimens from children who were evaluated to rule out either IBD or polyps, 10 of whom had ileal LNH (Table I). Additional biopsy specimens were obtained from all children, with informed parental consent, as approved by the local research ethics committee. There was no significant difference in the ages of the autistic, normal, and LNH groups, although the members of the IBD group were older.

None of the children with autism were included in our early report. ${ }^{1}$ All had been given a diagnosis within the autistic spectrum, confirmed by using Diagnostic and Statistical Manual of Mental Disorders, Fourth Edition criteria by M. Berelowitz. ${ }^{13}$ In 19 of 21 children, there had been loss of acquired language and development of autistic behaviors (median regression age, 18 months; range, 11-71 months). Only 2 had caused concern to parents or doctors in the first year of life. Two cases had other diagnoses in addition (oculocutaneous albinism, Marfan syndrome). There were 2 cases of Asperger's syndrome, one in association with epilepsy, and 19 cases of core autism. All 21 children had abdominal symptoms: 15 had pain, 13 had diarrhea or alternating constipation, 5 had rectal bleeding or mucus, and 9 had constipation. Twelve had a history of atopy. There was a history of atopy in a first-degree relative in 15 and organ-specific autoimmune disease in 7 . Subjects were enrolled con- secutively and excluded only if there was insufficient frozen tissue.

Ileal LNH was defined as multiple extruding follicles $>2 \mathrm{~mm}$ in diameter. ${ }^{5}$ Of the 8 normal control subjects, 2 had juvenile polyps and 1 had PeutzJeghers syndrome. Among the 10 control subjects with LNH who had chronic abdominal pain, poor weight gain, or rectal bleeding, several also showed disruption of the colonic vascular pattern. Subsequently, 9 of these 10 were found to be constipated with acquired megarectum, as determined from abdominal x-ray films; radiologic findings were similar to those of the autistic group. The children with IBD (Table I) were selected on the basis of secure diagnosis, active disease with typical histology, and availability of sufficient snap-frozen tissue.

\section{Biopsy Addesdment}

The colitis score was determined in blinded fashion with a modified O'Morain score. ${ }^{14}$ A score of 0 was histologically normal; 1 represented mononuclear cell infiltration; 2 , mononuclear infiltration with crypt distortion or mucosal atrophy; 3 , mild active inflammation with or without crypt abscesses, mild goblet cell depletion, or architectural change; 4 , moderate active inflammation with erosions and architectural changes; and 5 , severe active inflamation with epithelial ulceration.

Eosinophil density was assessed semiquantitatively from 0 (no eosinophils seen) to 4 (dense infiltrate), and epithelial damage was assessed from 0 (nor- 
Table II. Histologic findings in transverse colon of autistic children compared with histologically normal and disease control subjects

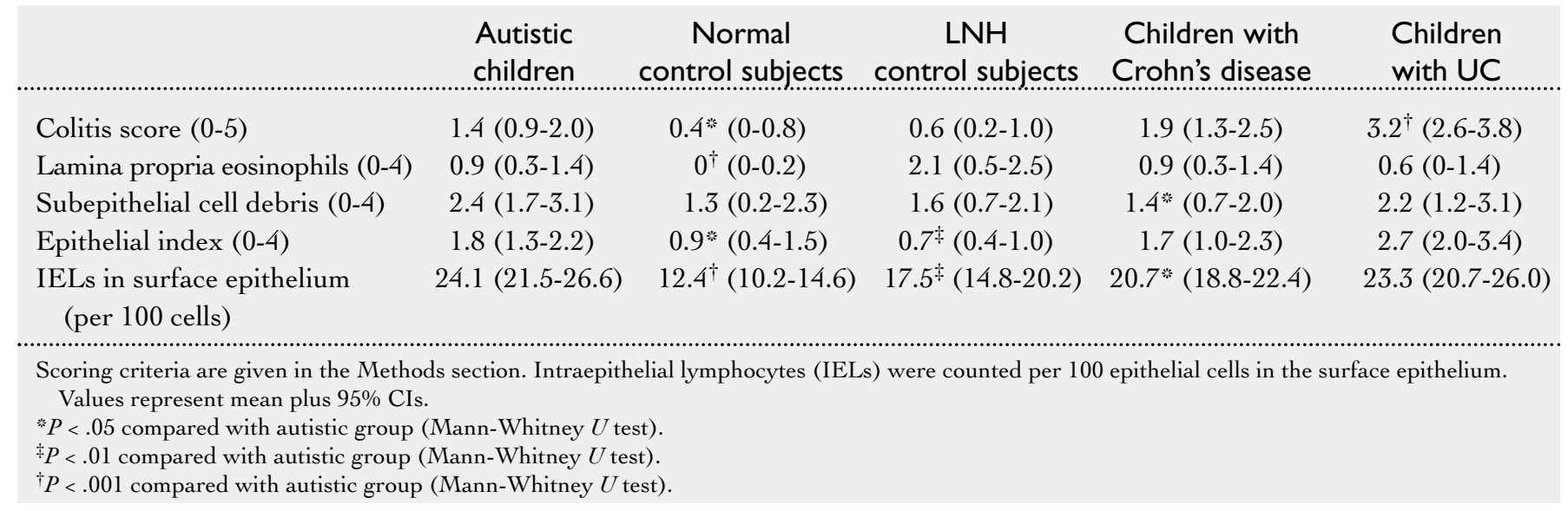

mal epithelium throughout) to 4 (erosion or ulceration). Presence of subepithelial nuclear debris was scored on a scale from 0 (no debris) to 4 (multiple dense foci). Intraepithelial lymphocyte numbers were determined by means of blinded counting in surface epithelium, over $\geq 3$ high-power fields. Biotin/ avidin immunohistochemistry (Vectastain Elite, Vector, U.K.) was used on 5 -mm cryosections with inactivation of endogenous peroxidase. Antibodies used were anti-CD3 (dilution 1:40), CD8 (1:25), Ki-67 (1:40), HLA-DR $(1: 40)$, and cytokeratin (1/40) from Dako, UK, syndecan-1 (1:50, Serotec, UK). Specimens with sufficient remaining tissue ( 6 normal, 6 LNH, 12 autistic, 5 Crohn's disease, and 6 UC) were re-cut to stain for $\gamma \delta$ T cells (TCR d1, T Cell Sciences, 1:25). Each staining run contained at least one batch from each disease group. $\mathrm{CD}^{+}, \mathrm{CD}^{+}$, $\gamma \delta^{+}$, and plasma cell density was assessed in blinded fashion by one of the authors (R.I.F.) using computerized image analysis (Imagan, Kompira). Reproducibility of counting was within $\pm 10 \%$. Periodic-acid Schiff staining, syndecan-1 immunohistochemistry, and cationic probe staining for sulfated glycosaminoglycans ${ }^{15}$ were performed on formalin-fixed specimens. Subepithelial basement membrane thickness was measured in periodic-acid Schiff-stained sections by computerized analysis. Density of
GAGs, HLA-DR, and epithelial Syndecan-1 was scored 0 (absent) to 4 (enhanced expression). Ki67 positivity was determined only in crypts sectioned along their full length to the surface epithelium, and tangentially sectioned crypts were excluded. A mean was obtained for each slide from at least 3 such crypts. For results with a clinical or histologic score, the mean and 95\% CIs were determined. For mucosal cell densities and basement membrane thickness, the mean and SE were determined. In all cases, differences between the autistic group and the others were assessed for statistical significance by using the Mann-Whitney $U$ test.

\section{RESULTS}

Elevation of inflammatory markers was seen only in the children with IBD (Table I). Three children in the LNH group and one autistic child had IgA $<0.5 \mathrm{~g} / \mathrm{L} . \mathrm{IgE}>100 \mathrm{kIU} / \mathrm{L}$ was seen in 6 of 21 children with autism. $\mathrm{IgG}_{1}$ above the age-standardized normal range was seen in 6 of 21 children with autism and 3 of 6 with $\mathrm{LNH}$, and $\mathrm{IgG}_{2}$ or $\mathrm{IgG}_{4}$ below the normal range was seen in 10 of 21 in the autistic group and 1 of 6 in the LNH group. Total lymphocyte values $<1.5 \times 10^{9} / \mathrm{L}$ were found in 1 control subject and in 2 patients with LNH, 9 with autism, and
1 with Crohn's disease. Circulating CD3, CD4, or CD8 T cells were below reference ranges in 12 of 21 of the children with autism.

The terminal ileum was visualized in all patients. Ileal LNH was detected in all 21 children with autism (2 Grade I [follicles 2-3 mm], 13 Grade II [3-5 $\mathrm{mm}$, 6 Grade III [ $>5 \mathrm{~mm}])$ and in all 10 in the LNH group (3 Grade I, 5 Grade II, 2 Grade III). The colon was macroscopically abnormal in all children with Crohn's disease and UC, was normal in all control subjects, and showed intermediate features in the autistic and LNH groups, more marked in the autistic group, with patchy loss of vascular pattern and mild granularity without contact bleeding. The endoscopic appearances were mild in all and were distinct from classical IBD.

\section{Histologic and \\ Immunobistologic Adsesdment}

Biopsy specimens demonstrated inflammation in the autistic children, greater than that of the control or LNH groups but milder than IBD (Table II). In 16 of 21, the appearances were abnormal, with 11 showing mild or moderate colitis and 5, patchy lymphocytic infiltration with focal surface abnormalities. Of the others, 2 showed prominent lymphoid follicles, 1 melanosis coli, and 2 no discernable abnormality. This contrasted with nor- 
mal control subjects, in whom only 3 cases showed minor abnormalities (1 increased eosinophils, 1 prominent lymphoid follicles, and 1 a mild increase in mucosal lymphocytes). Only 4 cases from the LNH group were normal, with minor abnormalities detected in 5 (excess lymphocytes or eosinophils) and mild colitis in the other case. In the Crohn's disease group, moderate or severe colitis was seen in 8 cases, 5 showed focal abnormality, and 2 were within normal limits. All of the UC biopsy specimens showed moderate or severe colitis. Focal neutrophil infiltration of crypts was seen in specimens obtained from 0 of 8 control subjects, 0 of 10 with LNH, 6 of 21 with autism, 4 of 15 with Crohn's disease, and 9 of 14 with UC. The colitis score in the autistic group was higher than the scores of the control and LNH groups but lower than that of the IBD group. The cellular infiltrate (predominantly lymphocytes, plasma cells, and macrophages) was located predominantly in the upper third of the lamina propria and was often particularly dense beneath the surface epithelium. Subepithelial deposition of nuclear dust and debris was particularly prominent in the autistic and UC groups. The LNH group showed the highest eosinophil score, despite the mild overall changes.

Immunohistochemistry demonstrated more significant lymphocyte infiltration in the children with autism than apparent on routine histologic examination, particularly $\mathrm{CD}^{+}$and $\gamma \delta \mathrm{T}$ cells (Figure, Table III). Overall CD3 ${ }^{+}$ density was significantly higher in the children with autism than in the control and LNH groups, similar to $\mathrm{CD}^{+}$ density in Crohn's disease, and lower than $\mathrm{CD}^{+}$density in UC. By contrast, in the autistic group, $\mathrm{CD}^{+}$density was similar to $\mathrm{CD}^{+}$density in $\mathrm{UC}$, and higher than $\mathrm{CD}^{+}$density in all other groups, including the Crohn's disease group. The density of $\gamma \delta$ cells was greater in the autistic group than in all others, usually with a predomi-
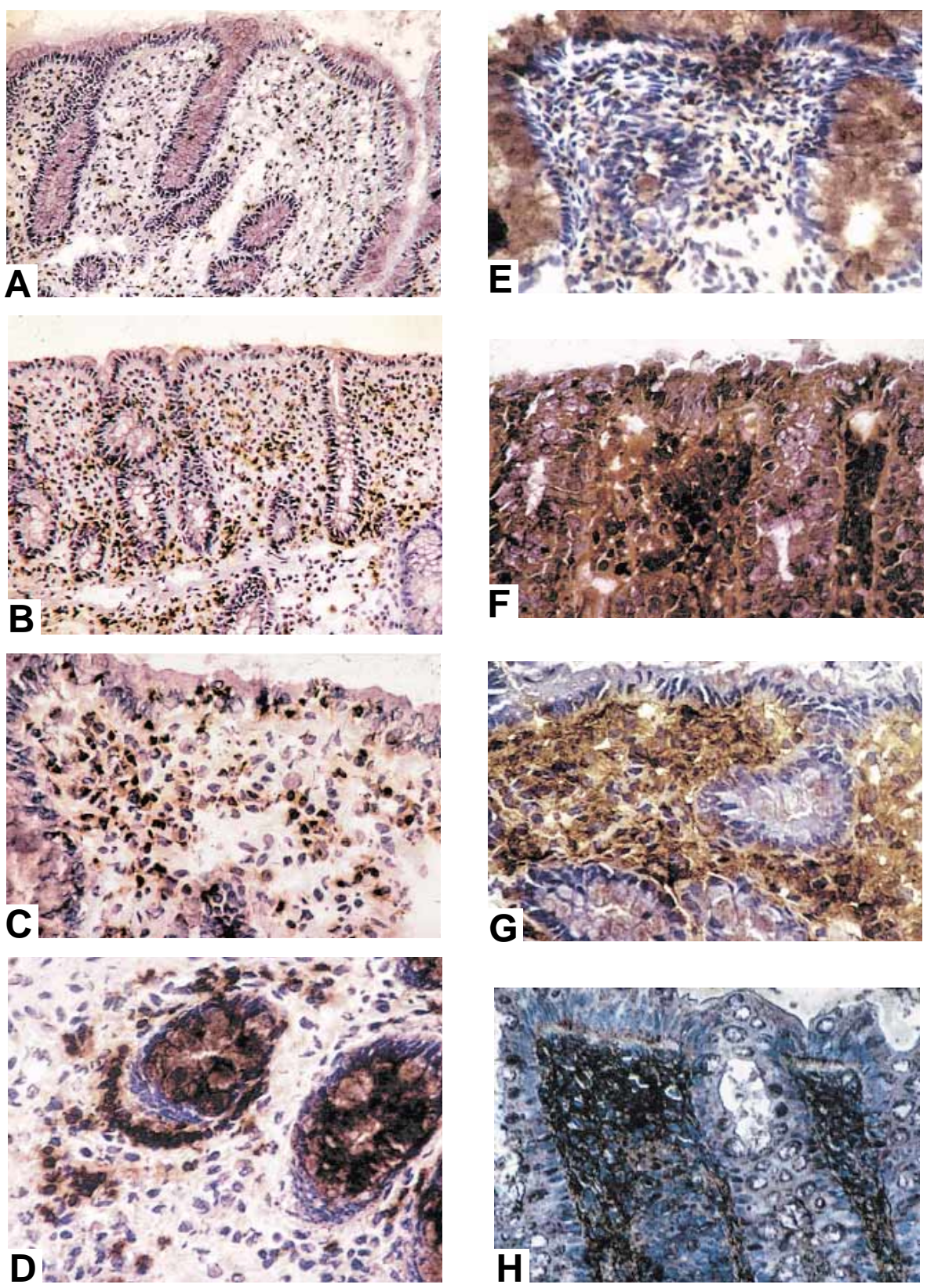

Figure. Immunohistochemical and histochemical findings. A, CD8 ${ }^{+} \mathrm{T}$ cells (brown staining) in transverse colon of typical child with $\mathrm{LNH}$ and constipation (original magnification $\times 20$ ). This density is similar to that seen in the normal control subjects, and there is no evidence of pericryptal aggregation of $\mathrm{T}$ cells. B, Contrasting dense infiltration of $\mathrm{CD} 8^{+}$cells within lamina propria of an autistic child at same magnification. There is clustering of CD8 cells around crypts, increased intraepithelial lymphocytes, and thinning of surface epithelium. $\mathbf{C}$, Large numbers of intraepithelial $\mathrm{CD} 3^{+} \mathrm{T}$ cells, with dense subepithelial aggregation, in another autistic child (original magnification $\times 40$ ). D, Dense aggregate of $\mathrm{CD} 3+\mathrm{T}$ cells around a colonic crypt in another autistic child; these were confirmed to be $\mathrm{CD}^{+}$on serial section (original magnification $\times 40$ ). $\mathbf{E}$, A dense infiltrate of $\gamma \delta \boldsymbol{T}$ cells in an autistic child (original magnification $\times 20$ ). This was not seen in classic IBD, despite increased severity of histologic inflammation compared with that of autistic children. F, Increased epithelial HLA-DR expression in Crohn's disease (original magnification $\times 20$ ). This is upregulated in response to $\gamma$-interferon production. There is also confluent staining in the lamina propria caused by class II major histocompatibility complex expression on macrophages and lymphocytes. G, Contrasting findings of negative epithelial HLA-DR staining in autistic child, despite lamina propria expression essentially similar to IBD (same magnification as E). H, Distribution of sulfated GAGs (black stain) in autism (original magnification $\times 20$ ). These are degraded by metalloproteases in inflammatory responses, such as IBD. Unlike children with IBD, those with autism show no inflammatory matrix degradation in the lamina propria, which shows a dense meshwork of anionic GAGs as in normal colon. However, there is clear undersulfation of a thickened basement membrane (white line beneath epithelium) and absence of the normal pericellular epithelial staining. 
Table III. Immunohistochemical findings in transverse colon of autistic children compared with histologically normal and disease control subjects, with mean cell densities $/ \mathrm{mm}^{2}$ of lymphocyte types within the lamina propria $( \pm \mathrm{SE})$

\begin{tabular}{|c|c|c|c|c|c|}
\hline & $\begin{array}{l}\text { Autistic } \\
\text { children }\end{array}$ & $\begin{array}{l}\text { Normal } \\
\text { control subjects }\end{array}$ & $\begin{array}{l}\text { Children } \\
\text { with LNH }\end{array}$ & $\begin{array}{l}\text { Children with } \\
\text { Crohn's disease }\end{array}$ & $\begin{array}{l}\text { Children } \\
\text { with UC }\end{array}$ \\
\hline $\mathrm{CD}^{+}$cells $\left(\right.$per $\left.\mathrm{mm}^{2}\right)$ & $1067( \pm 78)$ & $723^{*}( \pm 120)$ & $736 *( \pm 57)$ & $951( \pm 104)$ & $1320^{\dagger}( \pm 107)$ \\
\hline $\mathrm{CD}^{+}$cells $\left(\right.$per $\left.\mathrm{mm}^{2}\right)$ & $770( \pm 58)$ & $384^{\dagger}( \pm 45)$ & $427^{\dagger}( \pm 56)$ & $446^{\dagger}( \pm 50)$ & 840 \\
\hline$\gamma \delta$ Cells $($ per mm²) & $161( \pm 15)$ & $59^{\dagger}( \pm 5)$ & $87 *( \pm 56)$ & $54 *( \pm 3)$ & $100 \div( \pm 10)$ \\
\hline Plasma cells $\left(\right.$ Syndecan $\left.1^{+}\right)\left(\right.$per $\left.\mathrm{mm}^{2}\right)$ & $853( \pm 76)$ & $210^{\dagger}( \pm 33)$ & $277^{\dagger}( \pm 68)$ & $931( \pm 112)$ & $1049( \pm 159)$ \\
\hline Epithelial HLA-DR expression (0-4) & $0.3(0-0.5)$ & $0(0-0.2)$ & $0(0-0.2)$ & $1.7 *(1.2-2.2)$ & $2.2^{*}(1.6-2.9)$ \\
\hline $\begin{array}{l}\text { Proliferating epithelial cells }\left(\mathrm{Ki} 67^{+}\right) \\
\quad(\text { per } 100 \text { cells })\end{array}$ & $28.5(23.2-33.8)$ & 3) $11.2^{\dagger}(6.6-15.7)$ & $13.6^{\dagger}(6.5-20.7)$ & $31.6(20.4-42.6)$ & $49.7 \div(30.9-68.5)$ \\
\hline \multicolumn{6}{|c|}{$\begin{array}{l}\text { Epithelial HLA-DR expression was graded } 0-4 \text { (see Methods) and is presented with } 95 \% \text { CIs. The data for proliferating cells }\left(\text { Ki6 } 67^{+}\right) \text {within the } \\
\quad \text { epithelium are given per } 100 \text { cells. Ki6 } 67^{+} \text {cells were counted over longitudinally sectioned crypts only. } \\
\nexists P<.05 \text { compared with the autistic group (Mann-Whitney } U \text { test). } \\
* P<.01 \text { compared with the autistic group (Mann-Whitney } U \text { test). } \\
+P<.001 \text { compared with the autistic group (Mann-Whitney } U \text { test). }\end{array}$} \\
\hline
\end{tabular}

Table IV. Histochemical findings in transverse colon of autistic children compared with histologically normal and disease control subjects

\begin{tabular}{|c|c|c|c|c|c|}
\hline & $\begin{array}{l}\text { Autistic } \\
\text { children }\end{array}$ & $\begin{array}{c}\text { Normal } \\
\text { control subjects }\end{array}$ & $\begin{array}{c}\text { LNH } \\
\text { control subjects }\end{array}$ & $\begin{array}{l}\text { Children with } \\
\text { Crohn's disease }\end{array}$ & $\begin{array}{l}\text { Children } \\
\text { with UC }\end{array}$ \\
\hline Basement membrane thickness $(\mu \mathrm{m})$ & $3.1( \pm 0.1)$ & $2.2^{*}( \pm 0.1)$ & $2.1 *( \pm 0.1)$ & $2.2^{*}( \pm 0.2)$ & $2.0 *( \pm 0.2)$ \\
\hline GAGs in surface epithelium $(0-4)$ & $2.2(1.6-2.6)$ & $3.0^{\dagger}(2.7-3.3)$ & $3.1^{\dagger}(2.5-3.6)$ & $2.4(1.8-3.0)$ & $1.4^{\dagger}(1.0-1.7)$ \\
\hline $\begin{array}{l}\text { GAGs in subepithelial basement } \\
\text { membrane }(0-4)\end{array}$ & $2.1(1.6-2.6)$ & $3.0^{\dagger}(2.7-3.3)$ & $2.8^{\dagger}(2.4-3.1)$ & $2.5(1.9-3.1)$ & $1.9(1.3-2.5)$ \\
\hline GAGs within lamina propria $(0-4)$ & $3.1(2.9-3.3)$ & $2.8(2.5-3.1)$ & $2.9(2.7-3.1)$ & $2.5^{\dagger}(1.9-3.1)$ & $1.9 *(1.3-2.6)$ \\
\hline
\end{tabular}

nantly subepithelial distribution. Syndecan- $1^{+}$plasma cells were increased within the lamina propria in the autistic group to a level similar to that found in Crohn's disease and UC. Sulfated GAGs were not disrupted within the lamina propria, unlike Crohn's disease and $\mathrm{UC}$, in contrast to the changes within the epithelial compartment.

\section{Epithelial Changed}

Despite the subtle mucosal inflammation, the autistic group showed marked epithelial pathology (Figure, Tables II, III, and IV). The epithelial index was similar to that of Crohn's disease and UC. Total intraepithelial lymphocyte numbers were also signifi- cantly increased. Despite an increase in subepithelial HLA-DR expression, minimal expression was seen in surface epithelium in the autistic group (weakly detectable in 4/21). This contrasted with moderate or strong expression in almost all patients with IBD. Basement membrane thickness was also greater in the autistic group than in all other groups. The expression of epithelial Syndecan-1 was not significantly different from that of other groups, whereas cytokeratin expression was less intense in the children with autism. There was also enhanced crypt cell proliferation in the autistic group compared with the control and LNH groups, whereas sulfated GAGs were decreased in epithelium and basement membrane to a degree similar to IBD.

\section{Discussion}

This study extends our reports of colitis $^{1,2}$ in children with autism to demonstrate that autistic enterocolitis is distinct from classic IBD and is characterized by increased colonic infiltration of $\mathrm{T}$ cells and plasma cells, disproportionate to the inflammation seen on routine histologic examination. The epithelium and basement membrane also show distinct abnormalities. Similar basement membrane thicken- 
ing is seen in enteropathies associated with epithelial injury, such as tufting enteropathy, and $\gamma \delta$ cells play a role in protection of stressed epithelium. ${ }^{16}$ Thus our findings point to the epithelium as a potentially important target of this response. In support of this, sulfated GAGs were focally reduced in the basement membrane and epithelium, consistent with either inflammatory degradation ${ }^{15}$ or possibly a specific impairment of epithelial sulfation. ${ }^{11}$ There is also recent evidence to suggest that small bowel enteropathy also occurs in autistic children. ${ }^{12}$

It is important to note that the colonic lesion was often endoscopically and histologically subtle. This presents problems in diagnosis until a secure marker becomes available. Although there has been a consistent immunopathology in the children we have studied, it remains unclear whether they are representative of the main body of children with classical autism, without obvious gut symptoms. We are thus assessing noninvasive markers to allow better selection of children for evaluation. We have found that an increase of inflammatory markers is usually associated with more florid changes, when endoscopic assessment is indicated anyway. ${ }^{17}$ We obtain plain abdominal x-ray films at first assessment and currently restrict endoscopy to those with a clear history of GI symptoms or other evidence of immune dysregulation. Our practice is to treat even those in whom we do not perform endoscopy, if GI problems are uncovered, with active management of constipation, ${ }^{18}$ often followed by a supervised dietary exclusion of cow's milk and then wheat. Only if the child shows clear and significant cognitive responses do we recommend continuing dietary exclusions. For those with histologic inflammation, we are currently prescribing aminosalicylate treatment (usually mesalazine): this is only continued if the child shows improvement of GI and/or cognitive symptoms. ${ }^{18}$ Thus our management stratagems are broadly equivalent to those used in atopic nonautistic children with histologically confirmed GI inflammation or suspected food allergic dysmotility.

The functional significance of these findings is unclear, particularly because these children often have constipation rather than diarrhea. There is now evidence of antigen-induced constipation in atopic children, ${ }^{19,20}$ which may explain constipation in the $\mathrm{LNH}$ group, who overlap in other ways with the children with autism. There is also evidence in autism of excess absorption of dietary opiates, ${ }^{9,10}$ although it is unknown whether these will affect gut motility. Administration of $\beta$-casomorphine to rats induces behavioral abnormality and aberrant neural activation, suggesting a direct cognitive link. ${ }^{21,22}$

With international evidence of a marked increase in the incidence of autism, ${ }^{3,4}$ it is important to determine whether this relates to an upsurge in immunologically mediated (thus potentially treatable) disorders and whether intestinal inflammation is ubiquitous in such children. The high frequency of autoimmunity in families of children with autism ${ }^{23}$ suggests that immune dysfunction may be important in pathogenesis. Immunoglobulin deficiencies, low lymphocyte counts, and reduced T-cell activation have been reported, ${ }^{2,24,25}$ as have links with the complement $\mathrm{C} 4 \mathrm{~b}$ null allele and the "autoimmune" haplotype B44-C30DR4. ${ }^{24} \mathrm{C} 4$ deficiency may impair negative selection of $\mathrm{B}$ cells. ${ }^{26}$ Several autoantibodies against neural components have been reported. ${ }^{25,27,28}$ Children with autism show increased urinary neopterins, ${ }^{29}$ further evidence of immunopathology. Circulating lymphocytes show a pattern of partial activation, unusual in peripheral blood but not gut lymphocytes, ${ }^{30,31}$ and a $\mathrm{T}_{\mathrm{H}} 2$ skewed secretion pattern. ${ }^{32}$ The absence of epithelial HLA-DR in our patients, unlike those with IBD, also suggests a $\mathrm{T}_{\mathrm{H}} 2$-dominated response.

There may be analogy with celiac disease, which also manifests epithelial damage and a subtle and long-missed autoimmune component. ${ }^{33}$ The known links between celiac disease itself and a variety of neurologic abnormalities including autism suggest there may be a group of atypical autoimmune conditions in which the intestine and the brain are linked. It is clear that properly controlled clinical trials are needed, not least because desperate parents will understandably seek whatever may possibly help, and with modern communications, are exposed to a bewildering array of unvalidated claims. The increasing evidence of immunopathology suggests that focus on autoimmunity rather than genetics may now have become a priority.

This study could not bave been completed without the skill and expertise of the staff of Malcolm Ward and the Endoscopy Unit, Royal Free Hospital. We thank colleagues from the Departments of Haematology, Biochemistry, Immunology, and Radiology for their analyses of the children. We are most grateful to Dr Lei Lu of Massachusetts General Hospital for assistance with statistical analysis.

\section{REFERENCES}

1. Wakefield AJ, Murch SH, Anthony A, Linnell J, Casson DM, Malik M, et al. Ileal lymphoid nodular hyperplasia, non-specific colitis, and pervasive developmental disorder in children. Lancet 1998;351:637-41.

2. Wakefield AJ, Anthony A, Murch SH, Thomson M, Montgomery SM, Davies S, et al. Entero-colitis and immunodeficiency in children with developmental disorders. Am J Gastroenterol 2000;95:2285-95.

3. Taylor B, Miller E, Farrington CP, Petropoulos MC, Favot-Mayaud I, Li $\mathrm{J}$, et al. Autism and measles mumps and rubella vaccine: no epidemiological evidence for a causal association. Lancet 1999;353:2026-9.

4. Changes in the population of persons with autism and pervasive developmental disorders in California's Developmental Services system: 1987 through 1998. A report to the legislature. http://www.dds.ca.gov/autismreport.cfm.

5. Ojuawo A, St Louis D, Lindley KJ, 
Milla PJ. Non-infective colitis in infancy: evidence in favour of minor immunodeficiency in its pathogenesis. Arch Dis Child 1997;76:345-8.

6. Walker-Smith JA, Murch SH. Crohn's disease and abdominal tuberculosis. In: Diseases of the small intestine in childhood. 4th ed. Oxford, United Kingdom: Isis Medical Media; 1999. p. 299-328.

7. D'Eufemia P, Celli M, Finocchiaro R, Pacifico L, Viozzi L, Zaccaginini M, et al. Abnormal intestinal permeability in children with autism. Acta Paediatr 1996;85:1076-9.

8. Walker-Smith JA, Andrews J. Alpha1 antitrypsin, autism and coeliac disease. Lancet 1972;2:883-4.

9. Shattock P, Kennedy A, Rowell F, Berney TP. Role of neuropeptides in autism and their relationships with classical neurotransmitters. Brain Dysfunction 1991;3:328-45.

10. Reichelt KL, Hole K, Hamberger A, Saelid G, Edminson PD, Braestrup $\mathrm{CB}$, et al. Biologically active peptidecontaining fractions in schizophrenia and childhood autism. Adv Biochem Psychopharmacol 1981;28:627-43.

11. Waring RH, Ngong JM, Klovrza L, Green S, Sharp H. Biochemical parameters in autistic children. Dev Brain Dysfunction 1997;10:40-3.

12. Horvath K, Papadimitriou JC, Rabsztyn A, Drachenberg C, Tildon JT. Gastrointestinal abnormalities in children with autism. J Pediatr 1999;135: 559-63.

13. Volkmar FR, Klin A, Siegel B, Szatmari P, Lord C, Campbell M, et al. Field trials for autistic behaviour in DSM-IV. Am J Psychiatry 1994;151: 1361-7.

14. O'Morain CA, Abelow AC, Chervu LR, Fleischner GM, Das KM.
Chromium $_{51}$-ethylenediaminetetraacetate test: a useful test in the assessment of inflammatory bowel disease. J Lab Clin Med 1986;108:430-5.

15. Murch SH, MacDonald TT, WalkerSmith JA, Levin M, Lionetti P, Klein NJ. Disruption of sulphated glycosaminoglycans in intestinal inflammation. Lancet 1993;341:711-4.

16. Walker-Smith JA, Murch SH. Enterocyte proliferation and functions. In: Diseases of the small intestine in childhood. 4th ed. Oxford, United Kingdom: Isis Medical Media; 1999. p. 29-43.

17. Beattie RM, Walker-Smith JA, Murch $\mathrm{SH}$. Indications for investigation of chronic gastrointestinal symptoms. Arch Dis Child 1995;73:354-5.

18. Murch S, Thomson M, Walker-Smith J. Autism, inflammatory bowel disease, and MMR vaccine [letter]. Lancet 1998;351:908.

19. Iacono G, Cavataio F, Montalto G, Florena A, Tumminello M, Soresi M, et al. Intolerance of cow's milk and chronic constipation in children. N Engl J Med 1998;339:1100-4.

20. Shah N, Lindley K, Milla P. Cow's milk and chronic constipation in children. N Engl J Med 1999;340:891-2.

21. Sun $Z$, Cade JR, Fregly MJ, Privette RM. $\beta$-Casomorphin induces Fos-like immunoreactivity in discrete brain regions relevant to schizophrenia and autism. Autism 1999;3:67-83.

22. Sun Z, Cade JR. A peptide found in schizophrenia and autism causes behavioral changes in rats. Autism 1999; 3:85-95.

23. Comi AM, Zimmerman AW, Frye VH, Law PA, Peeden JH. Familial clustering of autoimmune disorders and evaluation of medical risks in autism. J Child Neurol 1999;14:388-94.
24. Warren RP, Singh VK, Averett RE, Odell JD, Maciulis A, Burger RA, et al. Immunogenetic studies in autism and related disorders. Mol Clin Neuropathol 1996;28:77-81.

25. Van Gent T, Heijnen CJ, Treffers PD. Autism and the immune system. J Child Psychol Psychiatr 1997;38:337-49.

26. Carroll MC. The lupus paradox. Nat Genet 1998;19:3-4.

27. Singh VK, Warren R, Averett R, Ghaziuddin M. Circulating autoantibodies to neuronal and glial filament proteins in autism. Pediatr Neurol 1997;17:88-90.

28. Singh VK, Lin SX, Yang VC. Serological association of measles virus and human herpesvirus- 6 with brain autoantibodies in autism. Clin Immunol Immunopathol 1998;89:105-8.

29. Messahel S, Pheasant AE, Pall H, Ahmed-Choudhury J, Sungum-Paliwal RS, Vostanis P. Urinary levels of neopterin and biopterin in autism. Neurosci Lett 1998;241:17-20.

30. Warren RP, Yonk J, Burger RW, Odell D, Warren WL. DR-positive T cells in autism: association with decreased plasma levels of the complement $\mathrm{C} 4 \mathrm{~B}$ protein. Neuropsychobiol 1995;31:53-7.

31. Abuzakouk M, Kelleher D, Feighery C, O'Farrelly C. Increased HLA-DR and decreased CD3 on human intestinal intraepithelial lymphocytes: evidence of activation? Gut 1996;39:396-400.

32. Gupta S, Aggarwal S, Rashanravan B, Lee T. Th1- and Th2-like cytokines in CD4 + and CD8+ T cells in autism. J Neuroimmunol 1998;85:106-9.

33. Walker Smith J, Murch S. Coeliac disease. In: Diseases of the small intestine in childhood. 4th ed. Oxford, United Kingdom: Isis Medical Media; 1999. p. 235-77. 